\title{
Build-up and decline of organic matter during PeECE III
}

\author{
K. G. Schulz ${ }^{1}$, U. Riebesell ${ }^{1}$, R. G. J. Bellerby ${ }^{2,3}$, H. Biswas ${ }^{1}$, M. Meyerhöfer ${ }^{1}$, M. N. Müller ${ }^{1}$, J. K. Egge $^{4}$, \\ J. C. Nejstgaard ${ }^{4}$, C. Neill ${ }^{2}$, J. Wohlers ${ }^{1}$, and E. Zöllner ${ }^{1}$ \\ ${ }^{1}$ Leibniz Institute for Marine Sciences (IFM-GEOMAR), Düsternbrooker Weg 20, 24105 Kiel, Germany \\ ${ }^{2}$ Bjerknes Centre for Climate Research, University of Bergen, Allégaten 55, 5007 Bergen, Norway \\ ${ }^{3}$ Geophysical Institute, University of Bergen, Allégaten 70, 5007 Bergen, Norway \\ ${ }^{4}$ University of Bergen, Department of Biology, Box 7800, 5020 Bergen, Norway
}

Received: 13 November 2007 - Published in Biogeosciences Discuss.: 30 November 2007

Revised: 7 April 2008 - Accepted: 7 April 2008 - Published: 6 May 2008

\begin{abstract}
Increasing atmospheric carbon dioxide $\left(\mathrm{CO}_{2}\right)$ concentrations due to anthropogenic fossil fuel combustion are currently changing the ocean's chemistry. Increasing oceanic $\left[\mathrm{CO}_{2}\right]$ and consequently decreasing seawater $\mathrm{pH}$ have the potential to significantly impact marine life. Here we describe and analyze the build-up and decline of a natural phytoplankton bloom initiated during the 2005 mesocosm Pelagic Ecosystem $\mathrm{CO}_{2}$ Enrichment study (PeECE III). The draw-down of inorganic nutrients in the upper surface layer of the mesocosms was reflected by a concomitant increase of organic matter until day $t_{11}$, the peak of the bloom. From then on, biomass standing stocks steadily decreased as more and more particulate organic matter was lost into the deeper layer of the mesocosms. We show that organic carbon export to the deeper layer was significantly enhanced at elevated $\mathrm{CO}_{2}$. This phenomenon might have impacted organic matter remineralization leading to decreased oxygen concentrations in the deeper layer of the high $\mathrm{CO}_{2}$ mesocosms as indicated by deep water ammonium concentrations. This would have important implications for our understanding of pelagic ecosystem functioning and future carbon cycling.
\end{abstract}

\section{Introduction}

Human activities such as the massive combustion of fossil fuels perturb the natural carbon cycle by increasing atmospheric carbon dioxide $\left(\mathrm{CO}_{2}\right)$ concentrations. Since the beginning of the industrial revolution atmospheric $\mathrm{CO}_{2}$ levels have increased already from about 280 to $380 \mu \mathrm{atm}$ in the year 2006 and are projected to reach values as high as $700 \mu \mathrm{atm}$, by the end of the $21 \mathrm{st}$ century (Prentice et al., 2001). Together with changes in other climatically active

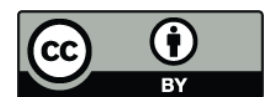

Correspondence to: $\mathrm{K}$. Schulz

(kschulz@ifm-geomar.de) gases this substantial increase in atmospheric $\mathrm{CO}_{2}$ drives global climate change: increasing global mean temperatures, rising sea level and accelerating extreme weather incidences, to name just those events most likely to happen (Meehl et al., 2007). As a result of atmosphere-ocean gas exchange increasing atmospheric $\mathrm{CO}_{2}$ levels are accompanied by concomitant increases of $\left[\mathrm{CO}_{2}\right]$ in ocean surface waters. This leads to a redistribution in the oceanic dissolved inorganic carbon (DIC) pool, resulting in increased ocean acidity on one hand and reduced carbonate saturation state on the other. This is manifested in decreasing ocean $\mathrm{pH}$ which is very likely to drop by about 0.4 units by the end of the 21 st century, adding to the 0.1 unit drop already observed since the beginning of the industrial revolution (Caldeira and Wickett, 2003).

Most of the marine organisms studied so far are known to be sensitive in some way or the other to changes in ocean chemistry (for a review see (Riebesell, 2005)). Marine biogenic calcification $\left(\mathrm{CaCO}_{3}\right.$ formation), for instance, by warm water corals, coccolithophores and foraminifera has been shown to decrease with decreasing $\mathrm{pH}$ and hence decreasing carbonate saturation (Gattuso et al., 1998; Kleypas et al., 1999; Riebesell et al., 2000; Russel et al., 2004). Although the response of biogenic $\mathrm{CaCO}_{3}$ production to changing ocean chemistry may differ between species (Langer et al., 2006) and is far from being understood, the calcareous shells of these organisms begin to dissolve when carbonate saturation drops below unity. This will probably happen towards the end of the 21 st century to another important group of pelagic calcifiers, the pteropods. Their natural habitats, the Southern Ocean and the subarctic Pacific, will become undersaturated with respect to their $\mathrm{CaCO}_{3}$ (aragonite) shells at increasing $\mathrm{CO}_{2}$ levels (Orr et al., 2005). Marine phytoplankton have also been shown to change their elemental composition $(\mathrm{C} / \mathrm{N} / \mathrm{P})$ in response to changing $\left[\mathrm{CO}_{2}\right]$ (Burkhardt and Riebesell, 1997; Burkhardt et al., 1999b). But again, these changes were species-specific, sometimes even with

Published by Copernicus Publications on behalf of the European Geosciences Union. 


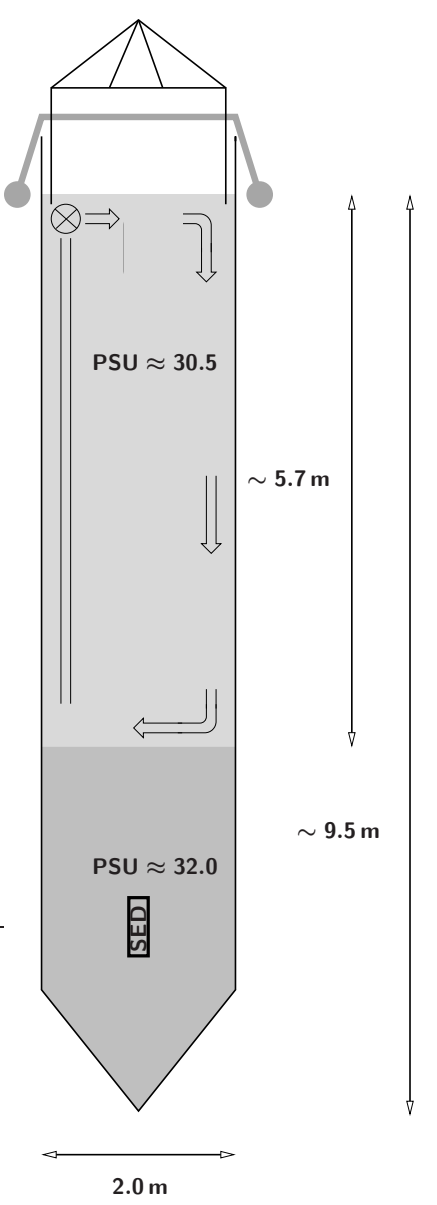

Fig. 1. Mesocosm design and setup. PSU denotes Salinity and SED the sediment trap. See text for details.

opposite sign. Furthermore, increases in $\mathrm{C} / \mathrm{N}$ can be the result of increased production of transparent exopolymer particles, TEP, (Engel, 2002) which are believed to be important for the export of particulate organic matter from the sunlit surface ocean to its interior (Engel et al., 2004). Whether carbon and nitrogen remineralization rates at depth could be affected by varying $\mathrm{C} / \mathrm{N}$ is another open question. Thus, increasing atmospheric and surface ocean $\mathrm{CO}_{2}$ levels have the potential to change the cycling of important elements in the ocean which could trigger important feedback responses in Earth's climate system.

While laboratory studies provide process based understanding at the organismal level, mesocosms are ideal for perturbation experiments at the community level. However, a good experimental design and setup is crucial for subsequent data interpretation. Here we describe the mesocosm setup and performance as well as the temporal development of the phytoplankton bloom in terms of build-up of particulate and dissolved organic matter and changes in respective carbon to nitrogen to phosphorus ratios for the 2005 Pelagic Ecosystem $\mathrm{CO}_{2}$ Enrichment study (PeECE III).

\section{Methods}

\subsection{Mesocosm setup and sampling}

In May 2005, in the Raunefjorden at the coastline of Norway $\left(\sim 60^{\circ} 16^{\prime} \mathrm{N}, 5^{\circ} 13^{\prime} \mathrm{E}\right)$ nine polyethylene bags (see Fig. 1 for a graphical representation), $2 \mathrm{~m}$ in diameter and extending about $9.5 \mathrm{~m}$ into depth, were deployed at a free floating raft, operated by the University of Bergen. The bags were filled simultaneously with unfiltered nutrient-poor fjord water, about $27 \mathrm{~m}^{3}$ each, pumped from $13.5 \mathrm{~m}$ depth. Three different $\mathrm{CO}_{2}$ levels $\sim 350 \mu \mathrm{atm}$ (mesocosms M7M9), $700 \mu \mathrm{atm}$ (mesocosms M4-M6) and $1050 \mu \mathrm{atm}$ (mesocosms M1-M3), termed hereafter $1 \times, 2 \times$ and $3 \times \mathrm{CO}_{2}$, representing present day $\mathrm{CO}_{2}$ conditions and those predicted for the year 2100 and 2150, respectively (Prentice et al., 2001), were set up in triplicate following in principle the approach described in (Engel et al., 2005).

Briefly, the enclosed fjord water was aerated at target $\mathrm{CO}_{2}$ levels for about two days until equilibration was reached. Then, about $0.8 \mathrm{~m}^{3}$ of freshwater were mixed into the upper $5.5 \mathrm{~m}$ by aquarium water pumps (flow rate $\sim 4501 \mathrm{~h}^{-1}$ ), creating a halocline with a salinity gradient of $\sim 1.5 \mathrm{psu}$ at about $5.7 \mathrm{~m}$ depth (see Fig. 1). The location and stability of the halocline, separating upper mixed surface from deep layer waters, was monitored daily by means of a CTD (SAIV A/S, model SD204), providing combined vertical distributions of salinity and temperature within the mesocosms (see Figs. 2 and 3, respectively). The operation of the aquarium water pumps within the upper surface layer throughout the experiment ensured homogeneous distribution of dissolved compounds and comparability of upper surface layer samples taken depth-integrated with those taken at discrete depths (see below). The mesocosm bags were covered with gas tight tents (ETFE foil) which allowed for the transmission of about $95 \%$ of the complete sunlight spectrum. Incident PAR, photosynthetic active radiation between 400 and $700 \mathrm{~nm}$, was measured continuously ( $15 \mathrm{~min}$ averages) with a Licor light sensor (LI-190) connected to a datalogger (LI-1400) mounted on the raft (see Fig. 4). On some days this photon flux density (PFD) was also measured within the headspace and at $2.5 \mathrm{~m}$ depth of mesocosm M8. The headspace within the tents was continuously flushed with air at target $\mathrm{CO}_{2}$ values throughout the experiment, simulating a $1 \times, 2 \times$ and $3 \times$ $\mathrm{CO}_{2}$ atmosphere.

The phytoplankton bloom was initiated on day $t_{-1}$ by additions of nitrate and phosphate to the upper surface layer, by means of a "reverse" sampling procedure (see below), aiming for final surface layer concentrations of 16 and $0.8 \mu \mathrm{mol} \mathrm{kg}^{-1}$, respectively (see Fig. 5a, b). However, in mesocosms 1, 2, 3 and 4 these concentrations were lower than expected as some of the nutrients added must have been lost to the deeper layer during mixing. Therefore, additional nitrate and phosphate was added to these mesocosms on day $t_{1}$, establishing uniform nutrient concentrations within all 

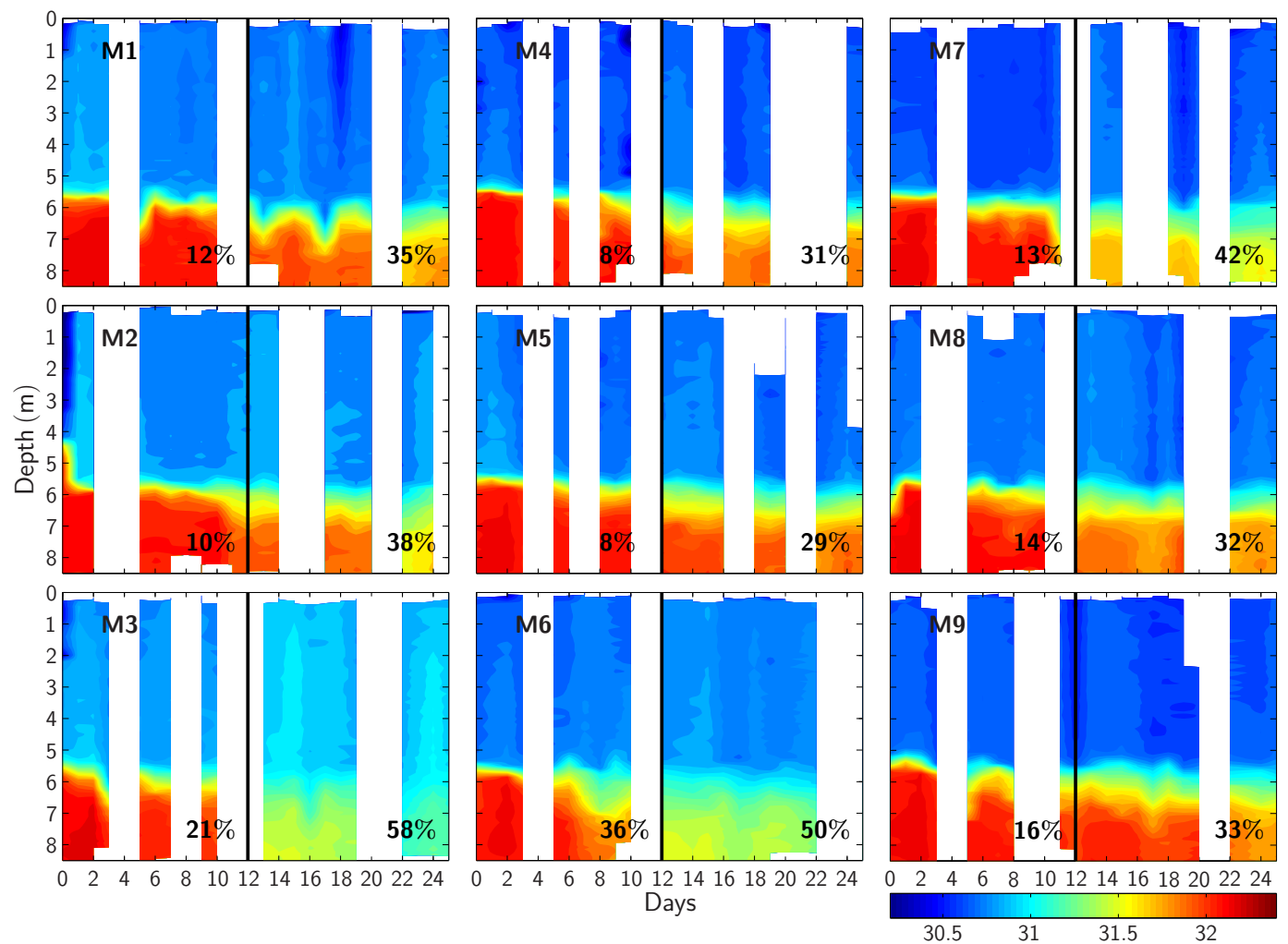

Fig. 2. Temporal changes in the vertical distribution of salinity within each mesocosm during the experiment. Mesocosms M1-M3 were set up at $\mathrm{CO}_{2}$ levels of $\sim 1050 \mu \mathrm{atm}$, mesocosms M4-M6 at $\sim 700 \mu \mathrm{atm}$ and mesocosms M7-M9 at $\sim 350 \mu$ atm. The black vertical lines mark the "storm event" around day 12. The loss of deep layer water into the upper $5.7 \mathrm{~m}$ by mixing was calculated from a simple mass balance. Numbers prior to day 12 denote the loss until day 10 while numbers after day 12 denote the loss until the end of the experiment.

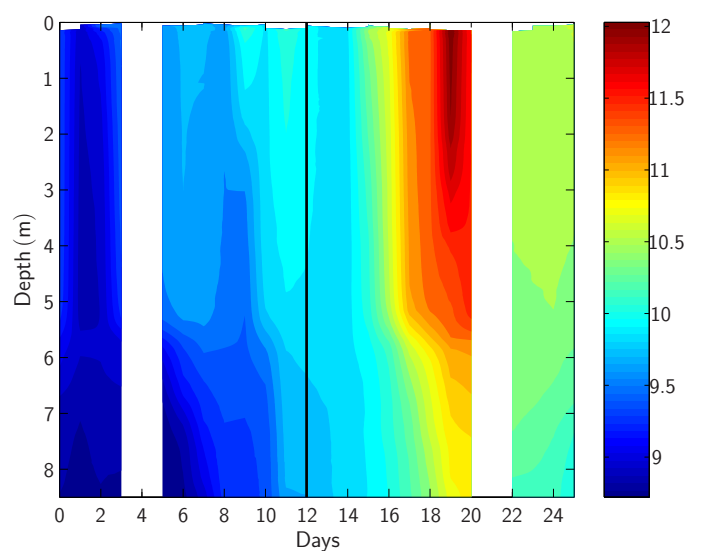

Fig. 3. Temporal changes in the vertical temperature distribution averaged along all nine mesocosms. Standard deviation between mesocosms was generally less than $0.1{ }^{\circ} \mathrm{C}$. The vertical black line marks the "storm event" around day 12.

mesocosms on day 2 (see Fig. 5). As $p \mathrm{CO}_{2}$ in mesocosms 1-6 were below intended values, $\mathrm{NaHCO}_{3}$ and equimolar amounts of $\mathrm{HCl}$ were added, leading to DIC increases of

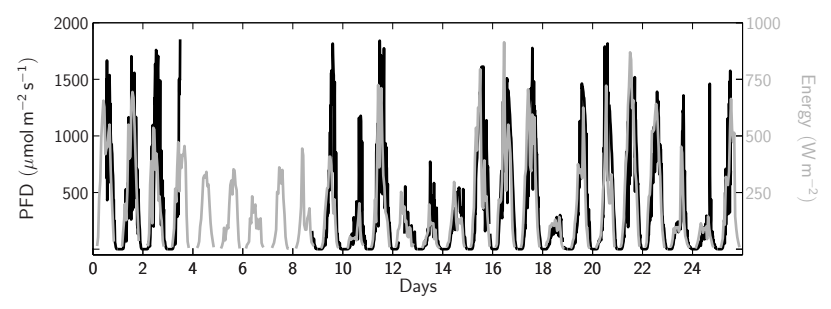

Fig. 4. Photon flux density (PFD) of incident photosynthetic active radiation between 400 and $700 \mathrm{~nm}$ (PAR) as measured on the raft (black line) and total amount of energy received as measured by the Geophysical Institute of the University of Bergen (grey line). See results section for details on PFDs within the mesocosms headspace and mixed surface layer.

$\sim 25$ and $\sim 18 \mu \mathrm{mol} \mathrm{kg}^{-1}$ in mesocosms $1-3$ and $4-6$, respectively. Regarding the changes in the $\mathrm{CO}_{2}$ system this procedure is equivalent to $\mathrm{CO}_{2}$ aeration and increased $p \mathrm{CO}_{2}$ in mesocosms $1-6$ to desired values of $\sim 700$ and $\sim 1050 \mu \mathrm{atm}$ on day 2 (see Fig. 6).

Daily sampling was at 10:00 a.m. starting on day $t_{0}$. Dissolved and particulate components (with the exception of 

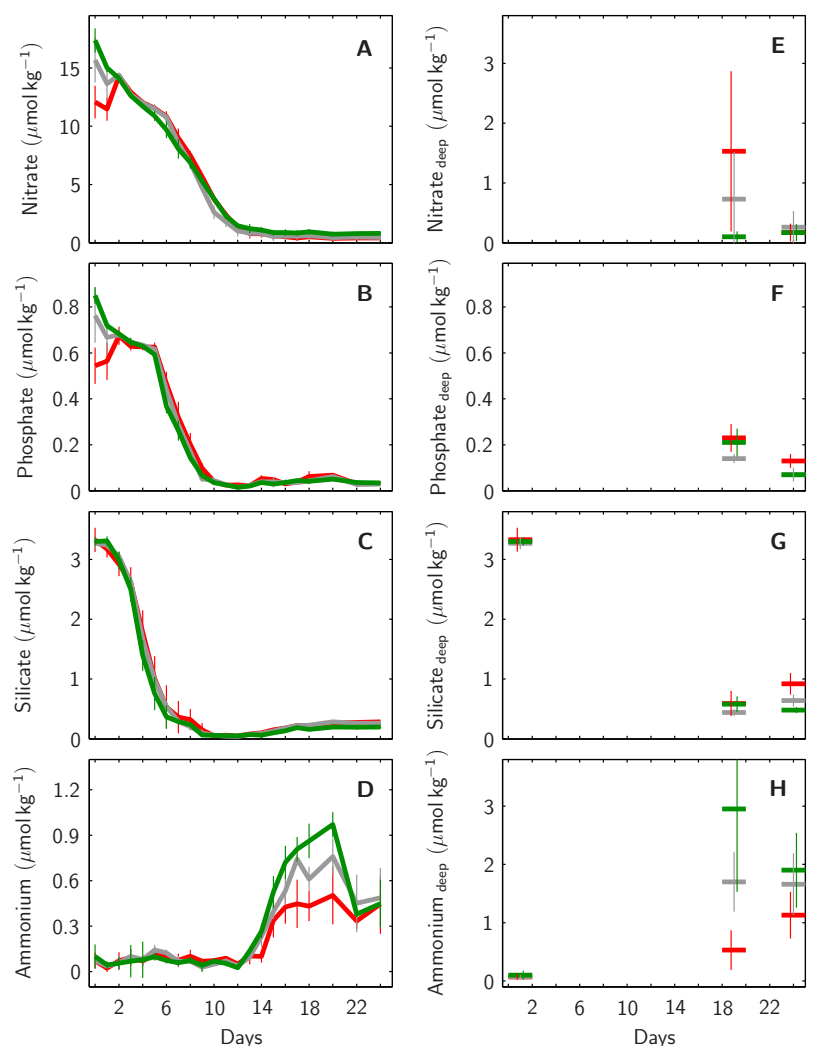

Fig. 5. Temporal development of major nutrient concentrations within the mesocosms' upper mixed layer. Green, grey and red lines illustrate average concentrations of (A) nitrate, $(\mathbf{B})$ phosphate, $(\mathbf{C})$ silicate and (D) ammonium within the $1 \times, 2 \times$ and $3 \times \mathrm{CO}_{2}$ mesocosms, respectively. Corresponding nutrient concentrations in the deep layer at selected days towards the end $\left(t_{20}\right.$ and $\left.t_{25}\right)$ of the experiment are shown in $(\mathbf{E}, \mathbf{F}, \mathbf{G})$ and $(\mathbf{H})$. Initial ammonium and silicate concentrations at depth were assumed to be identical to those in the upper mixed surface layer $(\mathbf{G}, \mathbf{H})$. Vertical lines denote standard deviations within each $\mathrm{CO}_{2}$ treatment $\left(1 \times, 2 \times, 3 \times \mathrm{CO}_{2}\right)$.

DIC, alkalinity, $p \mathrm{CO}_{2}$, and other gases) were sampled with a $5 \mathrm{~m}$ long, $\sim 6 \mathrm{~cm}$ diameter tube. The tube was lowered into the mesocosms and closed under water at its upper end with a stopper. The tube was then retrieved until a second stopper could be fitted under water at its other end, providing a depthintegrated sample. The samples, representative for the upper surface layer ( $\sim 25 \mathrm{~L}$ per mesocosm per day), were brought back to shore where sub-samples for various measurements and analyzes were taken immediately upon arrival. Every other day water from sediment traps, $60 \times 10 \mathrm{~cm}$ Plexiglas cylinders deployed in each mesocosm at $7.5 \mathrm{~m}$ depth, was also collected. Prior to deployment the cylinders were filled with $\mathrm{GF} / \mathrm{F}(0.7 \mu \mathrm{m}$ nominal pore size $)$ filtered sample water of the surface layer pooled from all mesocosms. The salinity of this water had been increased by about 2 psu above deep layer values with $\mathrm{NaCl}$ additions. Water from the deeper layer, sampled on day $t_{20}$ and $t_{25}$, was obtained by means of a hand-operated water sampler (Niskin-type).

\subsection{Measurement procedures}

In most cases measurements and analyzes of parameters presented in this article followed standard procedures. A complete list of all parameters measured together with their individual methods is given in Table 1. For details on measurement methods of parameters not presented in this article the reader is referred to the respective reference given in Table 1.

Nutrient analyzes were performed using an Autoanalyzer (AA II) on samples filtered through $\mathrm{GF} / \mathrm{F}$ (for nitrate, nitrite and phosphate) and $3 \mu \mathrm{m}$ cellulose acetate (for silicate) according to (Hansen and Koroleff, 1999). Ammonium was determined following the approach described in (Holmes et al., 1999). Ammonium was measured on triplicates, the other nutrients on duplicates.

For phytoplankton pigment analysis $250-500 \mathrm{ml}$ of sample water were filtered onto GF/F filters which immediately were frozen at $-20^{\circ} \mathrm{C}$ until extraction and analysis. For extraction filters were homogenized together with 2 and $4 \mathrm{~mm}$ glass beads in $2 \mathrm{ml} 100 \%$ acetone by a cooled $\mathrm{Vi}$ brogen cell mill for $5 \mathrm{~min}$. Thereafter samples were centrifuged at $\sim 3000 \mathrm{xg}$ and $-10^{\circ} \mathrm{C}$ for $10 \mathrm{~min}$. The supernatant was filtered through a $0.2 \mu \mathrm{m}$ polycarbonate filter and analyzed by rp-HPLC (reverse-phase high performance liquid chromatography) where pigments are identified by comparing retention times and absorption spectra, obtained with a diode array spectrophotometer (WATERS), with those of pigment standards. Commercially available pigments were also used as standards for calibration. All sample handling during the extraction and analysis procedures were carried out under dimmed light conditions to minimize the effect of pigment photo-oxidation. Calculation of the phytoplankton community composition and individual phytoplankton Chl- $a$ contributions was carried out with the program CHEMTAX (Mackey et al., 1996).

For determination of the particulate compounds TPC (total particulate carbon), POC (particulate organic carbon), PIC (particulate inorganic carbon), PON (particulate organic nitrogen), POP (particulate organic phosphorus) $250-500 \mathrm{ml}$ of sample water were filtered onto precombusted $\left(450^{\circ} \mathrm{C}\right.$ for $5 \mathrm{~h}) \mathrm{GF} / \mathrm{F}$ filters and stored at $-20^{\circ} \mathrm{C}$. TPC, POC, and PON were determined on an EuroVector elemental analyzer (EuroEA 3000). Prior to analysis all filters were dried for $6 \mathrm{~h}$ at $60^{\circ} \mathrm{C}$, while POC filters had been fumed overnight with concentrated $\mathrm{HCl}$ to remove PIC. Particulate inorganic carbon was then calculated as the difference between TPC and POC. PIC values obtained by this method compare extremely well with those derived from changes in total alkalinity (Bellerby et al., 2007), corrected for nitrate and phosphate consumption, indicating that overnight fuming was sufficient to remove all PIC. POP was oxidized by potassium persulphate to dissolved inorganic phosphorus which was measured as described by (Hansen and Koroleff, 1999). Every other day these measurements were also performed on 200-250 ml sub-samples collected from all nine sediment traps. 
Table 1. Measured parameters.

\begin{tabular}{|c|c|c|}
\hline Parameter & Method & Reference \\
\hline Temperature & $\mathrm{CTD}^{\dagger}$ & This article \\
\hline Salinity & $\mathrm{CTD}^{\dagger}$ & This article \\
\hline Alkalinity & Potentiometric Titration & Bellerby et al. (2007) \\
\hline DIC & Coulometry & Bellerby et al. (2007) \\
\hline$\delta^{13} \mathrm{C}_{\mathrm{DIC}}$ & Mass spectrometry & U. Ninnemann et al. \\
\hline$p \mathrm{CO}_{2}$ & Infrared analyzer Li-Cor 6262 & Bellerby et al. (2007) \\
\hline Nutrients & Autoanalyzer ${ }^{\dagger}$ & This article \\
\hline Trace metals & Voltammetry & E. Breitbarth, unpublished data \\
\hline Phytoplankton cell counts & Microscopy & V. Martin, unpublished data \\
\hline Phytoplankton and bacteria cell counts & Flowcytometry & Paulino et al. (2007) \\
\hline Pigments & HPLC $^{\dagger}$ & This article \\
\hline TPC, POC, PON & Elemental Analyzer $\dagger$ & This article \\
\hline POP & Colorimetry $^{\dagger}$ & This article \\
\hline PIC & TPC-POC & This article \\
\hline DOC, DON & $\mathrm{HTCO}^{\dagger}$ & This article \\
\hline DOP & Colorimetry $^{\dagger}$ & This article \\
\hline TEP & Colorimetry & J. Wohlers, unpublished data \\
\hline Mono-, Polysaccharides & Colorimetry & J. Wohlers, unpublished data \\
\hline Phosphorus uptake/affinity & ${ }^{33} \mathrm{PO}_{4}^{3-}$ & Tanaka et al. (2007) \\
\hline Primary Production & ${ }^{14} \mathrm{C}$ incubation, oxygen L/D method & Egge et al. (2007) \\
\hline C-fluxes & ${ }^{13} \mathrm{C}$ labelling of biomarkers & J. Middelburg, unpublished data \\
\hline Micro- and mesozooplankton & Microscopy & Antia et al. (2008), Suffrian et al. (2007) \\
\hline Copepod eggs and fecal pellets & Microscopy & Carotenuto et al. (2007) \\
\hline Bacterial diversity/production & DGGE & Allgaier et al. (2007) \\
\hline Glucose, APA affinity/turnover & ${ }^{14} \mathrm{C}$ labelling/Fluorometry & Tanaka et al.(2007) \\
\hline Viral density/diversity & Flowcytometry/DGGE,PFGE & Larsen et al. (2007) \\
\hline VOC in headspace & PTR-MS & Sinha et al. (2007) \\
\hline Organohalogens in headspace & GC-MS & 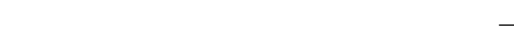 \\
\hline DMS, DMSP, DMSP lyase & $\mathrm{GC}$ & Vogt et al. (2007a); Vogt et al. (2007b) \\
\hline $\begin{array}{l}\text { Organic sulfur compounds, halocarbons, } \\
\text { hydrocarbons, alkyl nitrates }\end{array}$ & GC-FID-ECD-MS & Wingenter et al. (2007) \\
\hline Remineralization & Bottle incubations & NERI, Roskilde \\
\hline
\end{tabular}

$\dagger$ For details see Materials and methods section of this article.

The dissolved compounds DOC (dissolved organic carbon), DON (dissolved organic nitrogen) and DOP (dissolved organic phosphorus) were determined in GF/F filtered water samples. DOC and DON were analyzed by means of high temperature catalytic oxidation (HTCO) as described in (Qian and Mopper, 1996), DOP by potassium persulphate oxidation and subsequent dissolved inorganic phosphorus determination described in (Hansen and Koroleff, 1999).

\section{Results}

\subsection{Mesocosm performance}

Unlike in a previous mesocosm $\mathrm{CO}_{2}$ perturbation experiment (Engel et al., 2005), deep layer water was separated from the upper mixed surface by establishing a halocline. This allowed particulate organic matter produced in the nutrientenriched surface waters to settle to the deeper, more saline layer, simulating export production. Detailed monitoring of the location and stability of the halocline showed that until day $t_{12}$ deep water loss (mixing of deep waters into the surface waters and deepening of the halocline) was only moderate $(\sim 8-21 \%)$ in most mesocosms, with the exception of mesocosm M6 ( $\sim 36 \%)$. Unusually stormy weather conditions around day $t_{12}$, however, enhanced mixing of deep layer waters, and until the end of the experiment a substantial portion of the deep layer waters was lost in all mesocosms ( $\sim 29-$ $42 \%$ ) with up to $58 \%$ and $50 \%$ in mesocosms M3 and M6, respectively (Fig. 2).

Temperatures within the mesocosms, initially evenly distributed throughout depth at about $9^{\circ} \mathrm{C}$, increased to $\sim 11.5^{\circ} \mathrm{C}$ in upper surface and $\sim 11^{\circ} \mathrm{C}$ in the deep layer until day $t_{19}$ (Fig. 3). Towards the end of the experiment on 


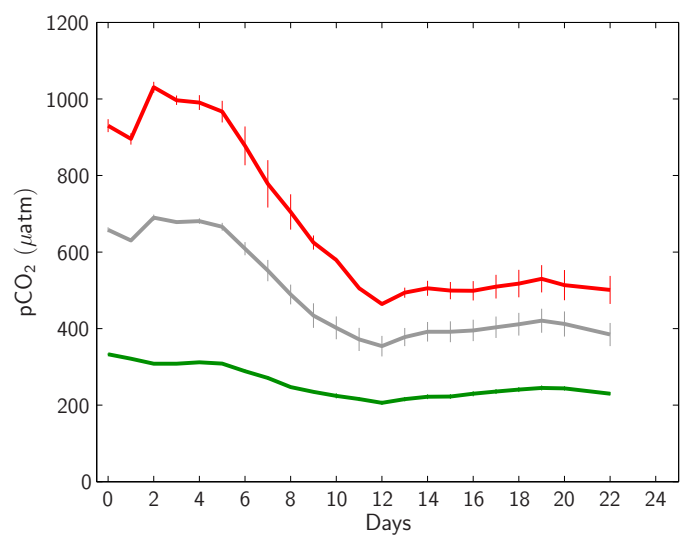

Fig. 6. Temporal development of $\mathrm{CO}_{2}$ partial pressures $\left(p \mathrm{CO}_{2}\right)$ within the mesocosms' upper mixed layer. Style and color-coding follow that of Fig. 5.

day $t_{25}$ temperatures were again distributed homogeneously, although slightly decreased, at about $10.5^{\circ} \mathrm{C}$.

Daily averaged incident photon flux densities measured on the raft varied between 90 and $560 \mu \mathrm{mol} \mathrm{m}^{-2} \mathrm{~s}^{-1}$. These fluctuations corresponded well with those measured in solar radiation at the University of Bergen (Fig. 4). About 80\% of incident PAR passed through the gas tight tents into the mesocosms' headspace of which up to $15 \%$ penetrated into $\sim 2.5 \mathrm{~m}$ depth, the center of the mixed surface layer (data not shown).

Having established desired $p \mathrm{CO}_{2}$ values within the mesocosms' surface layer of $\sim 350,700$ and $1050 \mu \mathrm{atm}$ at day $t_{2}, \mathrm{CO}_{2}$ partial pressure continuously decreased until day $t_{12}$ to $\sim 200,350$ and $460 \mu \mathrm{atm}$ in the $1 \times, 2 \times$ and $3 \times$ mesocosms, respectively. After a slight increase on day $t_{13}$ and $t_{14}$ $p \mathrm{CO}_{2}$ remained rather constant until the end of the experiment (Fig. 6).

All sediment traps, sampled every other day, showed significant over-trapping. In other words more particulate material was calculated to be exported into the deep than inorganic nutrients removed from the surface. This was probably caused by continuous flapping of the mesocosm bags mainly forced by wind stress which extended into depth and resuspension of sedimented particulate matter. Hence, rather than absolute concentrations only element ratios (POC/PON, $\mathrm{POC} / \mathrm{POP}$ and PON/POP) are reported in this study.

\subsection{Inorganic nutrient uptake and organic material build-up}

Following the addition of nitrate and phosphate on day $t_{-1}$ and their adjustment on day $t_{1}$ to 15 and $0.7 \mu \mathrm{mol} \mathrm{kg}^{-1}$ in all mesocosms, respectively, inorganic nutrients (nitrate, phosphate and silicate) continuously decreased in the upper surface layer (Fig. 5). In all mesocosms silicate was the first to get depleted about day $t_{7}$ (Fig. 5c), followed by phosphate about day $t_{10}$ (Fig. 5b) and nitrate about day $t_{13}$ (Fig. 5a).
From their day of depletion onwards all inorganic nutrient concentrations remained comparatively low. An exception were surface layer ammonium concentrations which were close to zero until day $t_{12}$ and increased up to $\sim 0.5,0.75$ and $0.9 \mu \mathrm{mol} \mathrm{kg}^{-1}$ until day $t_{20}$ in the $3 \times, 2 \times$ and $1 \times \mathrm{CO}_{2}$ mesocosms, respectively (Fig. 5d).

Data on corresponding nutrient concentrations in the mesocosms' deep layer were unfortunately collected only towards the end of the experiment on days $t_{20}$ and $t_{25}$ (Fig. 5e-f). While the concentrations of phosphate and silicate were relatively low (about $0.1-0.2$ and $0.5 \mu \mathrm{mol} \mathrm{kg}^{-1}$, respectively) in all mesocosms (Fig. 5f,g), deep layer ammonium concentrations were comparatively high with up to $3 \mu \mathrm{mol} \mathrm{kg}^{-1}$ in the $1 \times \mathrm{CO}_{2}$ treatments on day $t_{20}$. Moreover, there was a trend towards higher deep layer ammonium values in the $1 \times$ compared to the $2 \times$ and $3 \times \mathrm{CO}_{2}$ mesocosms, similar to what was observed in the mesocosms' surface layer (compare Fig. 5d, h). Interestingly, deep layer nitrate concentrations on day $t_{20}$ showed a reversed trend, i.e. higher values in the $3 \times$ compared to the $2 \times$ and $1 \times \mathrm{CO}_{2}$ treatments (Fig. 5e). If this finding, however, can be regarded to reflect $\mathrm{CO}_{2}$-mediated differences in certain deep layer processes is not clear, as standard deviations within treatments were relatively high. Moreover, on day $t_{25}$ this trend was gone.

The draw-down of inorganic nutrients was reflected by a concomitant build-up of organic matter. Total Chl- $a$ concentrations increased from about $1.5 \mu \mathrm{g} \mathrm{l}^{-1}$ on day $t_{0}$ to $\sim 11.0$, 13.5 and $13.0 \mu \mathrm{g}^{-1}$ on day $t_{10}$ in the $1 \times, 2 \times$ and $3 \times \mathrm{CO}_{2}$ mesocosms, respectively (Fig. 7a). From then on Chl- $a$ continuously decreased in all mesocosms, reaching again starting concentrations around day $t_{16}$. The comparatively small but significant increase of Chl- $a$ concentrations in all mesocosms around day $t_{20}$ might have been caused by increased ammonia concentrations at that time (compare Fig. 5d). Separating total Chl- $a$ concentrations into individual contributions by selected phytoplankton taxa showed that diatoms (mostly Skeletonema sp. and Nitzschia sp.) and prymnesiophytes (including Emiliania huxleyi) were of major importance, both reaching up to $\sim 5 \mu \mathrm{gl}^{-1}$ in all mesocosms. However, diatom associated Chl- $a$ peaked about day $t_{9}$ while that of prymnesiophytes coincided with the total Chl- $a$ maximum on day $t_{10}$ (Fig. 7b, c). During and after the decline of the phytoplankton bloom, from day $t_{10}$ onwards, prasinophyte, cyanobacteria and dinoflagellate Chl- $a$ concentrations were slightly increasing in all mesocosms (Fig. 7d, e, f).

The build-up of particulate organic carbon, nitrogen and phosphorus was very similar to that of Chl- $a$ with maximum values reached between days $t_{10}-t_{12}$. However POC, PON and POP concentrations did not decrease to starting values after the decline of the bloom. During the first 10 to 12 days, until the peak of the bloom, about $60-65 \mu \mathrm{mol}^{-1}$ of POC, $9-10 \mu \mathrm{moll}^{-1}$ of PON and $0.4 \mu \mathrm{moll}^{-1}$ of POP were building up in the upper $5.7 \mathrm{~m}$ of all mesocosms of which about $30-35 \mu \mathrm{moll}^{-1}$ of POC, 3.5-4.5 $\mu \mathrm{moll}^{-1}$ of PON and $0.15 \mu \mathrm{moll}^{-1}$ of POP remained until the end of 

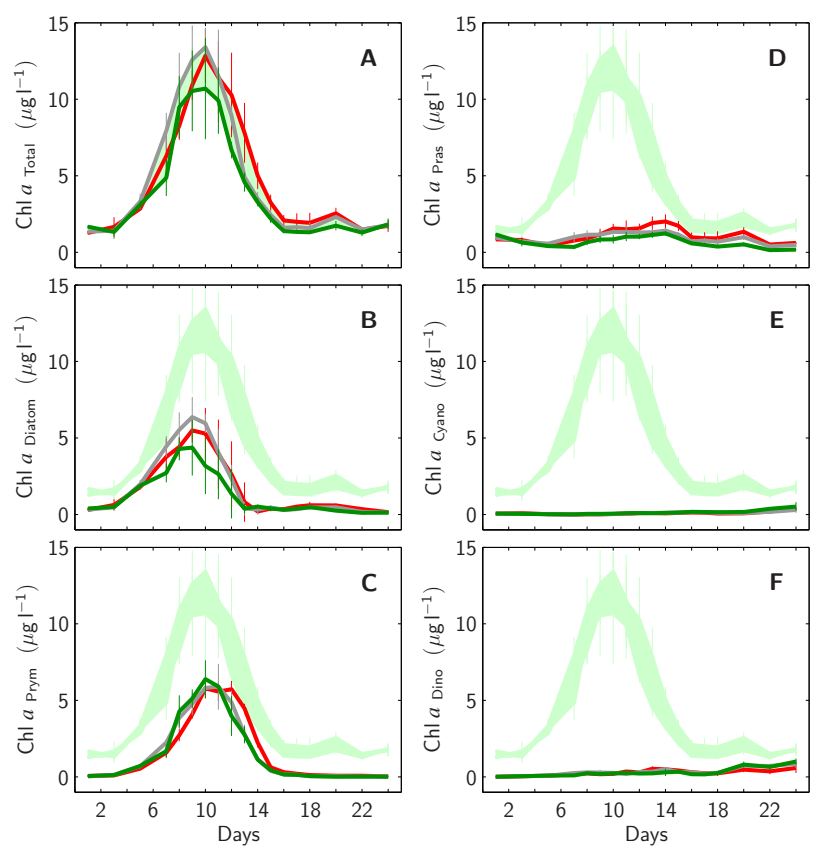

Fig. 7. Temporal development of Chl- $a$ concentrations within the mesocosms' upper mixed layer. Total Chl- $a$ concentrations (A) were measured by HPLC, while individual Chl- $a$ contributions by diatoms (B), prymnesiophytes (C), prasinophytes (D), cyanobacteria (E) and dinoflagellates $(\mathbf{F})$ have been calculated using the CHEMTAX algorithm (see methods for details). Shaded light green area depicts the temporal and spatial range of total Chl- $a$ within all mesocosms. Style and color-coding follow that of Fig. 5.

the experiment (Fig. 8a, b, c). Due to $\mathrm{CaCO}_{3}$ production of coccolithophores during the phytoplankton bloom (compare Fig. 7c), also about $15 \mu \mathrm{mol}^{-1}$ of PIC was build-up until the peak of the bloom, however almost all $\mathrm{CaCO}_{3}$ produced was lost from the upper mixed layer towards the end of the experiment (Fig. 8d). On the other hand, concentrations of all dissolved organic compounds increased steadily from day $t_{0}$ to day $t_{24}$ in all mesocosms, DOC from about 75 to $100 \mu \mathrm{moll}^{-1}$, DON from about 2.5 to $9.5 \mu \mathrm{moll}^{-1}$ and DOP from about 0.2 to $0.25 \mu \mathrm{moll}^{-1}$ (Fig. 8e, f, g).

Finally, in all mesocosms metazooplankton biomass increased from an average of about $0.7 \mu \mathrm{mol}$ carbon per liter at the beginning of the experiment to about 3.1-3.5 $\mu \mathrm{moll}^{-1}$ towards the end (Fig. 9). Part of this increase could be due to the exclusion of natural predators such as gelatinous plankton and planktivorous fish.

3.3 Element ratios of particulate and dissolved organic matter

Individual build-up and removal of both particulate and dissolved organic matter in the mixed surface layer led to specific temporal variations in the respective element ratios. The ratio of carbon to nitrogen to phosphorus of particu-
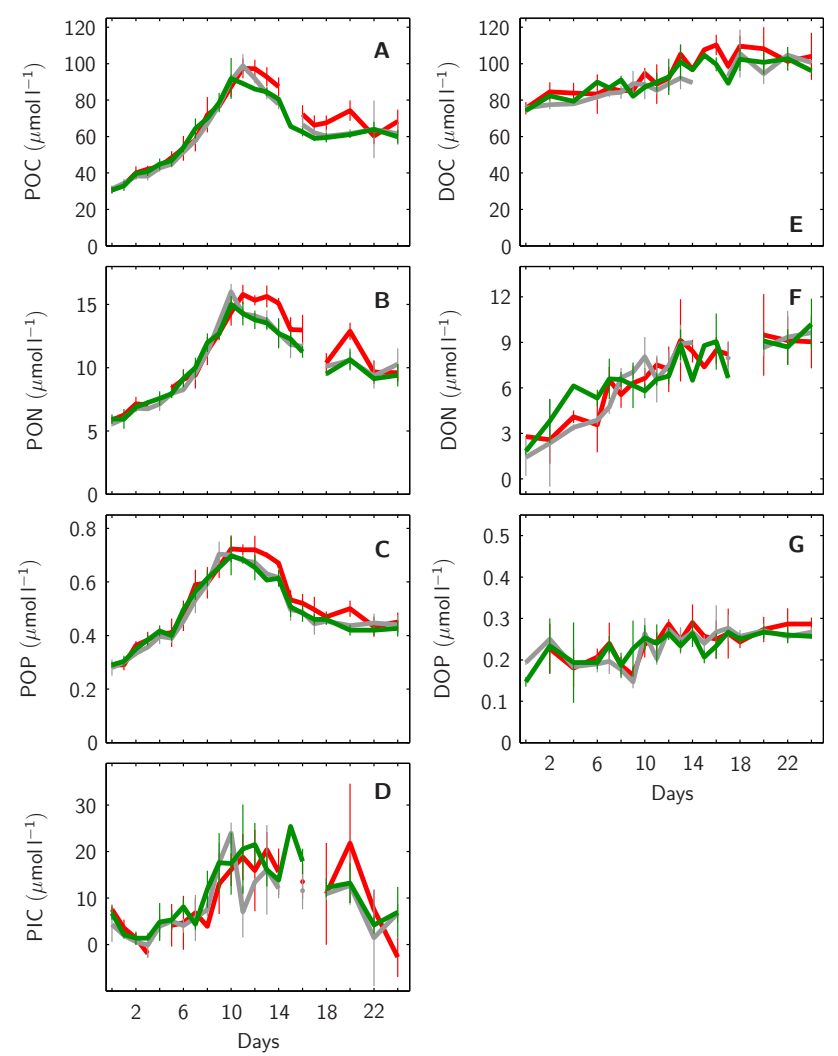

Fig. 8. Temporal development of organic matter within the mesocosms' upper mixed layer. Standing stocks of particulate organic matter POC (A), PON (B), POP (C) and PIC (D) are shown in comparison to those of dissolved organic matter DOC $(\mathbf{E})$, DON $(\mathbf{F})$ and DOP (G). Style and color-coding follow that of Fig. 5.

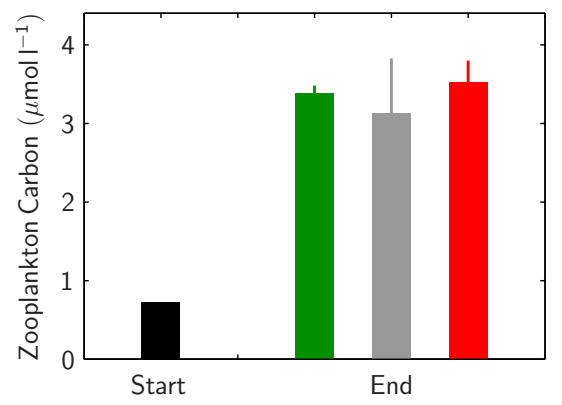

Fig. 9. Average metazooplankton $(>90 \mu \mathrm{m})$ organic carbon at the start (black) and at the end of the experiment in the $1 \times \mathrm{CO}_{2}$ (green), $2 \times \mathrm{CO}_{2}$ (grey) and $3 \times \mathrm{CO}_{2}$ (red) mesocosms. Vertical lines denote standard deviations.

late matter accumulating in the upper $5.7 \mathrm{~m}$ of all mesocosms was close to the corresponding Redfield values of 106/16/1 (POC/PON/POP) until about day $t_{9}$. From then on only POC/PON remained close to 6.625 while POC/POP and PON/POP increased about 2-fold to values of $\sim 200$ and 30, respectively (Fig. 10a, b, c). This can be the result 

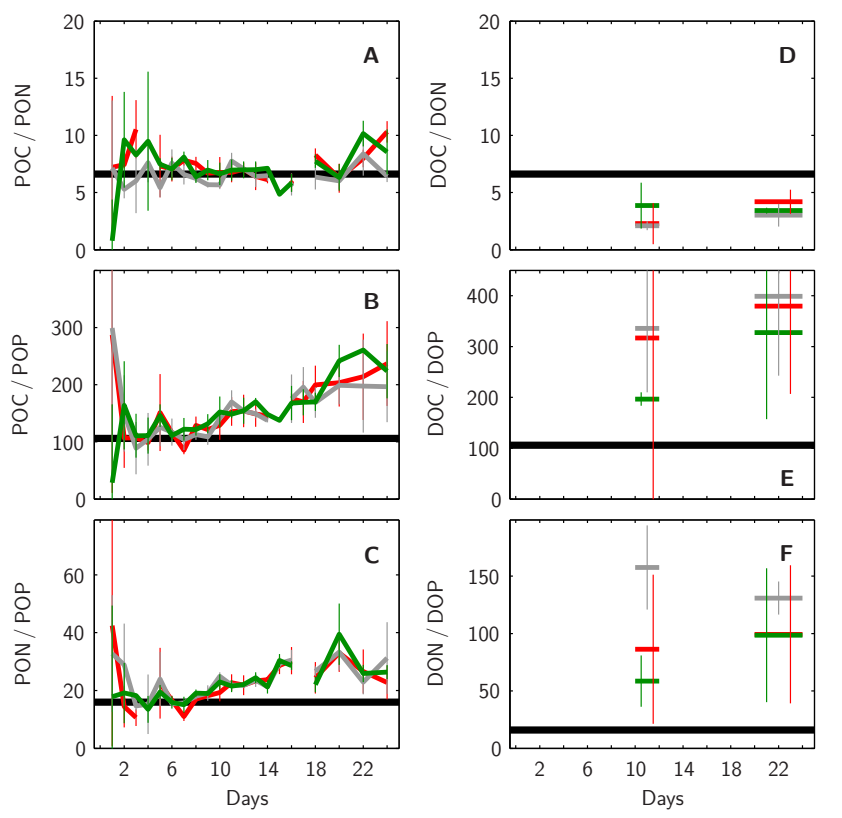

Fig. 10. Temporal development in element ratios of particulate organic and dissolved organic matter produced in the mesocosms' upper surface layer. Ratios shown are POC/PON (A), POC/POP (B), PON/POP (C), DOC/DON (D), DOC/DOP (E), and DON/DOP (F). Ratios of particulate organic matter were determined from organic matter build-up starting from $t_{0}-t_{1}$ averages in each mesocosm (A, $\mathrm{B}$ and C). Ratios of dissolved organic matter were estimated from corresponding build-up until the peak and end of the bloom, $t_{11}-t_{12}$ and $t_{20}-t_{24}$, respectively, starting from $t_{0}-t_{4}$ averages (D, E and F). Style and color-coding follow that of Fig. 5. Black horizontal lines denote respective Redfield ratios.

of preferential POP removal from the upper surface layer. The individual element ratios of the dissolved organic matter build-up during the experiment, however, did not seem to change with time but significantly deviated from Redfield values in all mesocosms. DOC/DON was relatively low with about 3, while DOC/DOP and DON/DOP were relatively high with values around 300 and 100, respectively (Fig. 10d, e, f). About $2 \times$ lower DOC/DON, $3 \times$ higher DOC/DOP and $6 \times$ higher DON/DOP in comparison to the corresponding Redfield ratios can be the result of either relatively higher DOP than DOC than DON removal or relatively lower DOP than DOC than DON build-up within the upper surface layer.

The ratios of carbon to nitrogen to phosphorus of the particulate organic material collected in the sediment traps reflect processes of accumulation and remineralization, both in the deep layer water column and the sediment building up on the bottom of the mesocosms. In all mesocosms POC/PON in the sediment traps was close to Redfield ratios throughout the experiment (Fig. 11) as were the corresponding values in the upper surface layer (compare Fig. 10a, b, c). POC/POP and PON/POP in the sediment traps increased after about 14 days to higher ratios, however, apparently higher in the $3 \times$ than $2 \times$ than $1 \times \mathrm{CO}_{2}$ mesocosms.

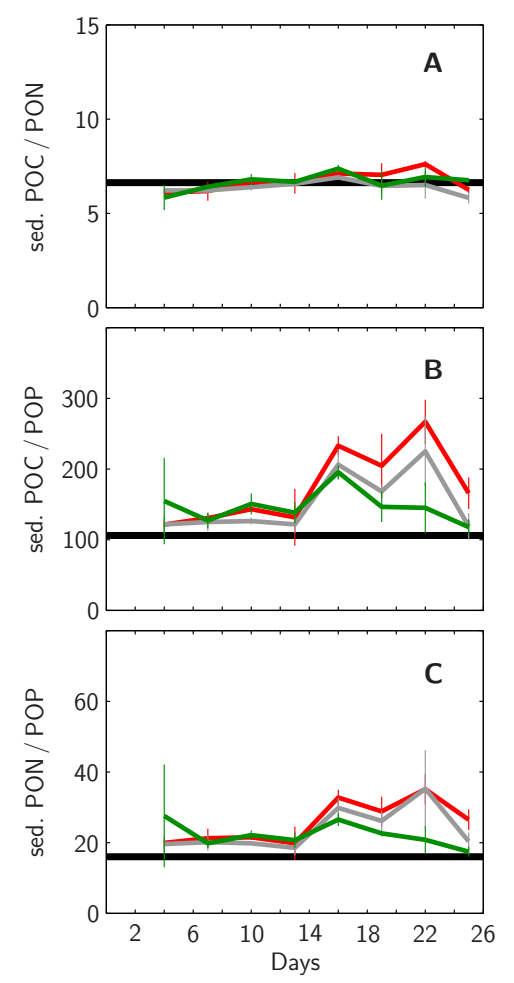

Fig. 11. Temporal development in elemental ratios of particulate organic matter sampled by sediment traps. Note that this material is most likely a mix of freshly settled and old "re-worked" matter. Shown are sedimentary ratios of POC/PON (A), POC/POP (B), and PON/POP (C). Style and color-coding follow that of Fig. 5. Black horizontal lines denote respective Redfield ratios.

\section{Discussion}

\subsection{Mesocosm performance}

The 2005 PeECE III mesocosm experiment differs from earlier studies in several aspects, the most important being the establishment of a halocline. This was thought to create two distinct water masses in which key pelagic processes such as primary production (surface layer) and remineralization (deeper layer) are separated. Any water exchange between these two realms makes data interpretation difficult as most efforts in this study were directed towards sampling in the upper surface layer. Hence, the stability and location of the halocline was monitored on a daily basis. However, even without the storm event on day $t_{12}$, substantial water mixing from the deeper layer into the upper surface occurred, probably caused by the wind force acting on the bags that was transmitted to depth. This would also explain the observed over-trapping of the sediment traps caused by significant resuspension of settled particulate organic matter. Hence, sedimentation processes appear to be difficult to evaluate with this kind of mesocosm setup. For future mesocosm 
experiments we recommend frequent sampling in both the upper and deeper water layers as only this will allow for complete element budgets and process assessment of primary production, export and remineralization.

\subsection{Inorganic nutrient uptake and organic material build-up}

The draw-down of the major nutrients nitrate, phosphate and silicate in the upper surface layer during the bloom phase of the experiment followed the same temporal pattern in all mesocosms, irrespective of $p \mathrm{CO}_{2}$ (for details see Bellerby et al., 2007). The same was observed for the concomitant build-up of Chl- $a$ and particulate organic matter (POC,PON and POP). Only on selected days a statistically significant difference in these bulk parameters was found (ANOVA). There were $p \mathrm{CO}_{2}$ treatment effects in Chl- $a$ concentrations on days $t_{13}, t_{14}, t_{15}, t_{16}$ and $t_{20}$, in POC on $t_{12}$ and $t_{20}$, in PON on $t_{12}, t_{18}$ and $t_{20}$, and in POP on $t_{12}, t_{13}, t_{14}$ and $t_{20}$. All these days were after the main bloom phase and after the storm event when significant amounts of deep layer water were mixed into the upper surface waters. Hence, inferring a $p \mathrm{CO}_{2}$ related treatment effect on particulate organic matter build-up doesn't seem justified. The steady increase in dissolved organic material (DOC, DON, DOP) on the other hand, was not significantly different between $\mathrm{CO}_{2}$ treatments. The same was found for the build-up of metazooplankton $(>90 \mu \mathrm{m})$ biomass. In summary, the temporal development of nutrient uptake, build-up and decline of particulate organic matter and increase of dissolved organic matter during the experiment was not affected by initial $\mathrm{CO}_{2}$ conditions (compare Engel et al., 2005). The similarity of nutrient uptake and corresponding organic matter build-up between treatments indicates that phytoplankton nutrient utilization (nitrate and phosphate) and division rates were insensitive to changes in seawater $p \mathrm{CO}_{2}$. Indeed, although there is a critical $\mathrm{CO}_{2}$ concentration for all phytoplankton species below which their growth decreases, in the $\mathrm{CO}_{2}$ range of the present study (350-1050 $\mu \mathrm{atm})$ division rates of diatoms, coccolithophores and cyanobacteria have been found to be rather constant (Burkhardt et al., 1999a; Rost et al., 2002; Langer et al., 2006; Barcelos e Ramos et al., 2007). Changes in phytoplankton $\mathrm{C} / \mathrm{N}$ and $\mathrm{C} / \mathrm{P}$ stoichiometry due to variations of seawater $p \mathrm{CO}_{2}$ would then have to be explained by changes in inorganic carbon utilization (see below).

Another interesting finding is that the increase of deep and surface layer ammonium concentrations towards the end of the experiment was strongest in the $1 \times \mathrm{CO}_{2}$ mesocosms and also higher in the $2 \times$ than in the $3 \times \mathrm{CO}_{2}$ treatments. This is clearly driven by a process occurring in the deeper layer of the mesocosms as increasing ammonium concentrations start to build-up in the surface layer right after the storm event when deeper water masses were mixed into the upper surface layer. The differences between $\mathrm{CO}_{2}$ treatments are relatively large in comparison to those observed for Chl$a$, POC, PON and POP. Timing (after the bloom phase) and origin (the deeper layer) of the increase in ammonium exclude autotrophic photorespiration as a significant driver and point to a process dominated by heterotrophic activities. The two remaining processes impacting ammonium concentrations are remineralization of organic nitrogen compounds and nitrification. Hence, lower ammonium concentrations towards higher seawater $\mathrm{CO}_{2}$ could be caused by decreased rates of nitrogen remineralization (reduced ammonium production) and/or higher rates of nitrification (increased ammonium consumption). Nitrification in sediments (note that the water in the deep layer of the mesocosms is probably highly impacted by the microbial processes taking place in the organic material sedimented on the bottom of the mesocosms) is known to be regulated by a number of factors of which only $\mathrm{pH}$ and oxygen concentration could have been different between $\mathrm{CO}_{2}$ treatments (for a review see (Strauss et al., 2000)). However, nitrification rates were found to be positively correlated with $\mathrm{pH}$ (Sarathchandra, 1978), which would favor higher rates in the $1 \times$ compared to the $2 \times$ and $3 \times \mathrm{CO}_{2}$ mesocosms with the opposite effect on ammonium concentrations than observed (compare Fig. 5h). Regarding deep layer oxygen concentrations (which were unfortunately not measured), the positive correlation of nitrification rates with dissolved oxygen would argue for higher oxygen concentrations and hence more ammonium consumption in the deep layer of the $3 \times$ compared to the $2 \times$ and $1 \times \mathrm{CO}_{2}$ mesocosms. However, we have good reason to assume that if deep layer oxygen concentrations were different between treatments they would have been rather lower in the $3 \times$ than the $2 \times$ and $1 \times \mathrm{CO}_{2}$ mesocosms. Although standing stocks of dissolved and particulate organic carbon in the upper surface layer were quite similar in all mesocosms, significantly more dissolved inorganic carbon was utilized in the $3 \times$ than in the $2 \times$ and than in the $1 \times \mathrm{CO}_{2}$ mesocosms (for details see (Riebesell et al., 2007) and (Bellerby et al., 2007)). This implies that considerably more organic carbon must have been lost into the deeper layer, about twice as much in the $3 \times$ compared to the $1 \times \mathrm{CO}_{2}$ mesocosms (Riebesell et al., 2007). The process operating could be enhanced TEP formation (Arrigo, 2007) which has been shown to be higher at elevated $\mathrm{CO}_{2}$ (Engel, 2002), leading to intensified particle coagulation and hence organic carbon export from the surface to depth. Intensified organic carbon sedimentation at higher $\mathrm{CO}_{2}$ levels could have fueled organic carbon remineralization by heterotrophic bacteria, leading to stronger oxygen reduction at depth in the $3 \times$ than in the $2 \times$ and than in the $1 \times \mathrm{CO}_{2}$ mesocosms. If only half of the additional organic carbon exported in the $3 \times \mathrm{CO}_{2}$ mesocosms would have been remineralized in the lower $1.5 \mathrm{~m}$ of the mesocosms, oxygen would have been considerably stronger depleted at depth in comparison to the $2 \times$ and $1 \times \mathrm{CO}_{2}$ mesocosms, by about $100 \mu \mathrm{mol} \mathrm{kg}^{-1}$ at the end of the experiment. Another, more direct indication for higher oxygen depletion in the deeper layer water of the $3 x$ compared to the $1 \times \mathrm{CO}_{2}$ mesocosms comes from oxygen measurements in the upper surface layer of mesocosms M2 
and M8. Until the peak of the bloom and prior to the storm event on day $t_{12}$ oxygen concentrations increased to values about $20 \mu \mathrm{mol} \mathrm{kg}^{-1}$ higher in the $3 \times$ compared to the $1 \times$ $\mathrm{CO}_{2}$ treatment, indicating enhanced net primary production at elevated $\mathrm{CO}_{2}$ (Riebesell et al., 2007). After the storm event and subsequent mixing of deep layer water into the upper surface of the mesocosms this difference, however, decreased to about $5 \mu \mathrm{mol} \mathrm{kg}^{-1}$ until the end of the experiment (data not shown), indicating enhanced deep layer water oxygen depletion in the $3 \times$ compared to the $1 \times \mathrm{CO}_{2}$ treatment.

As nitrification, ammonium regeneration in sediments appears to be correlated with oxygen with steadily decreasing rates at decreasing oxygen concentrations (Chapelle, 1995; Serpa et al., 2007). Thus, we conclude (from the sparse data at hand) that the negative correlation of deep layer ammonium concentrations with seawater $\mathrm{CO}_{2}$ was more likely caused by reduced ammonium regeneration rates rather than higher nitrification rates in the $3 \times$ compared to the $2 \times$ and $1 \times \mathrm{CO}_{2}$ mesocosms. Alternatively, a direct $\mathrm{pH}$ sensitivity of the enzymes involved in ammonification and/or nitrification could explain the observed differences between $\mathrm{CO}_{2}(\mathrm{pH})$ treatments.

4.3 Element ratios of particulate and dissolved organic matter

While in the surface layer element ratios of particulate and dissolved organic matter reflect processes of production and removal, corresponding ratios in the deeper layer of the mesocosms are indicative for processes of accumulation and remineralization. Until day $t_{9}$ element ratios of particulate organic matter were close to corresponding Redfield ratios. As from then on inorganic phosphorus was depleted while nitrate and dissolved inorganic carbon could still be assimilated, POC/POP and PON/POP steadily increased. The same trend was found for dissolved organic matter, although due to relatively high standard deviations statistically not significant. Interestingly, however, DOC/DON was considerably lower than the Redfield ratio, indicating preferential loss of dissolved organic carbon compared to dissolved organic nitrogen in all mesocosms. This can be the result of TEP formation, favoring preferential DOC export from the surface waters to depth (compare Sect. 4.2). In this context it is also important to note that the loss of organic matter from the surface, defined as the difference between organic matter buildup and the inorganic counterparts drawn-down, seems to be a process in operation right from the start of the experiment (data not shown but compare Riebesell et al., 2007).

Balancing the processes of accumulation and remineralization at depth is difficult because of the problems associated with sediment trap sampling and the lack of dissolved organic matter data in the deep layer. Moreover, the material collected every other day in the sediment traps was most likely a mix of relatively young material, freshly settled from the upper surface layers, and older material from the bottom of the mesocosms, being subject to increasing remineralization. However, the scenario described above of 1) increased loss of organic carbon from surface waters to depth at elevated $\mathrm{CO}_{2}$, resulting in 2) increased respiration of this organic carbon and hence increased oxygen consumption at depth, and hence in 3) reduced organic nitrogen remineralization (ammonium regeneration) is not at odds with the observed patterns in sedimentary organic matter ratios. Constant sedimentary POC/PON, for instance, could indicate increased organic carbon remineralization at elevated $\mathrm{CO}_{2}$. Furthermore, increased sedimentary PON/POP in the $3 \times$ and $2 \times$ in comparison to the $1 \times \mathrm{CO}_{2}$ mesocosms could be the result of decreased PON remineralization.

4.4 The pelagic ocean in a high $\mathrm{CO}_{2}$ world: indications from mesocosm studies

Bulk parameters of natural phytoplankton blooms, especially those representative for biomass such as POC, PON, POP, Chl- $a$, but also DOC, DON and DOP appear to a great extent insensitive to changing $\mathrm{CO}_{2}$ conditions (compare Engel et al., 2005). Also corresponding elemental ratios of these standing stocks appear largely unaffected by seawater $p \mathrm{CO}_{2}$. However, in this study there were pronounced treatment differences in the calculated amount of organic carbon lost from the upper surface layer, with higher values in the $3 \times$ compared to the $2 \times$ and $1 \times \mathrm{CO}_{2}$ mesocosms (compare Riebesell et al., 2007). This was fueled by significantly increased dissolved inorganic carbon (DIC) to inorganic nutrient (nitrate, phosphate) uptake ratios at elevated $\mathrm{CO}_{2}$ (compare Bellerby et al., 2007). Hence, elemental ratios of organic matter exported from surface to depth must have been enriched in organic carbon compared to nitrogen and phosphorus under elevated $\mathrm{CO}_{2}$ conditions. Furthermore, this "extra" organic carbon could have resulted in higher bacterial respiration and oxygen consumption at depth, reducing ammonium regeneration in the $3 \times$ compared to the $2 \times$ and to the $1 \times \mathrm{CO}_{2}$ mesocosms.

In summary, mesocosm studies have identified various processes in pelagic ecosystems potentially sensitive to increasing atmospheric $\mathrm{CO}_{2}$ (for details see ?). However, whether changes in these processes will dampen or enhance global climate change is still impossible to forecast.

Acknowledgements. We gratefully acknowledge the staff of the Espegrend Marine Biological Station, University Bergen, in particular T. Sørlie and A. Aadnesen, and the Bergen Marine Research infrastructure (RI) for helping organize and set up the mesocosm experiment. We also thank J. Barcelos e Ramos for processing the salinity data, and H.-P. Grossart, M. Vogt and J. Williams for helpful comments on the manuscript.

Edited by: S. W. A. Naqvi 


\section{References}

Allgaier, M., Riebesell, U., Vogt, M., Thyrhaug, R., and Grossart, H.-P.: Coupling of heterotrophic bacteria to phytoplankton bloom development at different $p \mathrm{CO}_{2}$ levels: a mesocosm study, Biogeosciences Discuss., 5, 317-359, 2008, http://www.biogeosciences-discuss.net/5/317/2008/.

Antia, A. N., Suffrian, K., Holste, L., Mller, M. N., Nejstgaard, J. C., Simonelli, P., Carotenuto, Y., and Putzeys, S.: Dissolution of coccolithophorid calcite by microzooplankton and copepod grazing, Biogeosciences Discuss., 5, 1-23, 2008, http://www.biogeosciences-discuss.net/5/1/2008/.

Arrigo K. R.:Carbon cycle - Marine manipulations, Nature, 450, 491-492, 2007.

Barcelos e Ramos, J., Biswas, H., Schulz, K. G., LaRoche, J., and Riebesell, U.: Effect of rising atmospheric carbon dioxide on the marine nitrogen fixer Trichodesmium, Global Biogeochem. Cy., 21, GB2028, doi:10.1029/2006GB002898, 2007.

Bellerby, R. G. J., Schulz, K. G., Riebesell, U., Neill, C., Nondal, G., Johannessen, T., and Brown, K. R.: Marine ecosystem community carbon and nutrient uptake stoichiometry under varying ocean acidification during the PeECE III experiment, Biogeosciences Discuss., 4, 4631-4652, 2007,

http://www.biogeosciences-discuss.net/4/4631/2007/.

Burkhardt, S. and Riebesell, U.: $\mathrm{CO}_{2}$ availability affects elemental composition (C:N:P) of the marine diatom Sceletonema costatum, Mar. Ecol. Prog. Ser., 155, 67-76, 1997.

Burkhardt, S., Riebesell, U., and Zondervan, I.: Effects of growth rate, $\mathrm{CO}_{2}$ concentration, and cell size on the stable carbon isotope fractionation in marine phytoplankton, Geochim. Cosmochim. Acta, 63, 3729-3741, 1999a.

Burkhardt, S., Zondervan, I., and Riebesell, U.: Effect of $\mathrm{CO}_{2}$ concentration on the $\mathrm{C}: \mathrm{N}: \mathrm{P}$ ratio in marine phytoplankton: A species comparision, Limnol. Oceanogr., 44, 683-690, 1999 b.

Caldeira, K. and Wickett, M. E.: Anthropogenic carbon and ocean pH, Nature, 425, p. 365, 2003.

Carotenuto, Y., Putzeys, S., Simonelli, P., Paulino, A., Meyerhfer, M., Suffrian, K., Antia, A., and Nejstgaard, J. C.: Copepod feeding and reproduction in relation to phytoplankton development during the PeECE III mesocosm experiment, Biogeosciences Discuss., 4, 3913-3936, 2007,

http://www.biogeosciences-discuss.net/4/3913/2007/.

Chapelle, A.: A preliminary model of nutrient cycling in sediments of a Mediterranean lagoon, Ecol. Mod., 80, 131-147, 1995.

Delille, B., Harlay, J., Zondervan, I., Jacquet, S., Chou, L., Wollast, R., Bellerby, R. G. J., Frankignoulle, M., Borges, A. V., Riebesell, U., and Gattuso, J.-P.: Response of primary production and calcification to changes of $\mathrm{pCO}_{2}$ during experimental blooms of the coccolithophorid Emiliania huxleyi, Global Biogeochem. Cy., 19, GB2023, doi:10.1029/2004GB002318, 2005.

Egge, J. K., Thingstad, T. F., Engel, A., and Riebesell, U.: Primary production during nutrient-induced blooms at elevated $\mathrm{CO}_{2}$ concentrations, Biogeosciences Discuss., 4, 4385-4410, 2007, http://www.biogeosciences-discuss.net/4/4385/2007/.

Engel, A.: Direct relationship between $\mathrm{CO}_{2}$ uptake and transparent exopolymer particles production in natural phytoplankton, J. Plankt. Res., 24, 49-53, 2002.

Engel, A., Thoms, S., Riebesell, U., Rochelle-Newall, E., and Zondervan, I.: Polysaccharide aggregation as a potential sink of marine dissolved organic carbon, Nature, 428, 929-932, 2004.
Engel, A., Zondervan, I., Aerts, K., Beaufort, L., Benthien, A., Chou, L., Delille, B., Gattuso, J.-P., Harlay, J., Heemann, C., Hoffmann, L., Jacquet, S., Nejstgaard, J., Pizay, M. D., RochelleNewall, E., Schneider, U., Terbrueggen, A., and Riebesell, U.: Testing the direct effect of $\mathrm{CO}_{2}$ concentration on a bloom of the coccolithophorid Emiliania huxleyi in mesocosm experiments, Limnol. Oceanogr., 50, 493-507, 2005.

Gattuso, J.-P., Frankignoulle, M., Bourge, I., Romaine, S., and Buddemeier, R. W.: Effect of calcium carbonate saturation of seawater on coral calcification, Global Planet. Change, 18, 37-46, 1998.

Hansen, H. P. and Koroleff, F.: Determination of nutrients, in: Methods of seawater analysis, 3. Ed., edited by: Grasshoff, K., Kremling, K., and Ehrhardt, M., Wiley VCH, Weinheim, 159228, 1999.

Holmes, R. M., Aminot, A., Kérouel, R., Hooker, B. A., and Peterson, B. J.: A simple and precise method for measuring ammonium in marine and freshwater ecosystems, Can. J. Fish. Aquat. Sci., 56, 1801-1808, 1999.

Kleypas, J. A., Buddemeier, R. W., Archer, D., Gattuso, J.-P., Langdon, C., and Opdyke, B. N.: Geochemical consequences of increased atmospheric carbon dioxide on coral reefs, Science, 284, 118-120, 1999.

Langer, G., Geisen, M., Baumann, K. H., Kläs, J., Riebesell, U., Thoms, S., and Young, J. R.: Species-specific responses of calcifying algae to changing seawater carbonate chemistry, Geochem. Geophys. Geosystems, 7, Q09006, doi:10.1029/2005GC001227, 2006.

Larsen, J. B., Larsen, A., Thyrhaug, R., Bratbak, G., and Sandaa, R.-A.: Response of marine viral populations to a nutrient induced phytoplankton bloom at different $p \mathrm{CO}_{2}$ levels, Biogeosciences, 5, 523-533, 2008, http://www.biogeosciences.net/5/523/2008/.

Mackey, M. D., Mackey, D. J., Higgins, H. W., and Wright, S. W.: CHEMTAX - a program for estimating class abundances from chemical markers: application to HPLC measurements of phytoplankton, Mar. Ecol. Prog. Ser., 144, 265-283, 1996.

Meehl, G. A., Stocker, T. F., Collins, W. D., Friedlingstein, P., Gaye, A. T., Gregory, J. M., Kitoh, A., Knutti, R., Murphy, J. M., Noda, A., Raper, S. C. B., Watterson, I. G., Weaver, A. J., and Zhao, Z.-C.: Global Climate Projections, In: Climate Change 2007: The Physical Science Basis, Contribution of Working Group I to the Fourth Assessment Report of the Intergovernmental Panel on Climate Change, edited by: Solomon, S., Qin, D., Manning, M., Chen, Z., Marquis, M., Averyt, K. B., Tignor, M., and Miller, H. L., Cambridge University Press, Cambridge, United Kindom and new York, NY, USA, 747-845, 2007.

Orr, J. C. Fabry, V. J., Aumont, O., Bopp, L., Doney, S. C., Feely, R. A., Gnanadesikan, A., Gruber, N., Ishida, A., Joos, F., Key, R. M., Lindsay, K., Maier-Reimer, E., Matear, R., Monfray, P., Mouchet, A., Najjar, R. G., Plattner, G. K., Rodgers, K. B., Sabine, C. L., Sarmiento, J. L., Schlitzer, R., Slater, R. D., Totterdell, I. J., Weirig, M. F., Yamanaka, Y., and Yool, A.: Anthropogenic ocean acidification over the twenty-first century and its impact on calcifying organisms, Nature, 437, 681-686, 2005.

Paulino, A. I, Egge, J. K., and Larsen, A.: Effects of increased atmospheric $\mathrm{CO}_{2}$ on small and intermediate sized osmotrophs during a nutrient induced phytoplankton bloom, Biogeosciences Discuss., 4, 4173-4195, 2007, 
http://www.biogeosciences-discuss.net/4/4173/2007/.

Prentice, I. C., Farquhar, G. D., Fasham, M. J. R., Goulden, M. L., Heimann, M., Jaramillo, V. J., Kheshgi, H. S., Le Quéré, C., Scholes, R. J., and Wallace, D. W. R.: The Carbon Cycle and Atmospheric Carbon Dioxide, in: Climate Change 2001: The Scientific Basis, Contribution of Working Group I to the Third Assessment Report of the Intergovernmental Panel on Climate Change, edited by: Houghton, J. T., Ding, Y., Griggs, D. J., Nougher, M., van der Linden, P. J., Dai, X., Maskell, K., and Johnson, C. A., Cambridge University Press, Cambridge, United Kindom and new York, NY, USA, 183-237, 2001.

Qian, J. and Mopper, K.: Automated High-Performance, HighTemperature Combustion Total Organic Carbon Analyzer, Anal. Chem., 68, 3090-3097, 1996.

Riebesell, U.: Effects of $\mathrm{CO}_{2}$ Enrichment on Marine Phytoplankton, J. Oceanogr., 60, 719-729, 2005.

Riebesell, U., Zondervan, I., Rost, B., Tortell, P. D., Zeebe, R. E., and Morel, F. M. M.: Reduced calcification of marine plankton in response to increased atmosphe ric $\mathrm{CO}_{2}$, Nature, 407, 364-367, 2000.

Riebesell, U., Schulz, K. G., Bellerby, R. G. J., Botros, M., Fritsche, P., Meyerhöfer, N., Neill, C., G., N., Oschlies, A., Wohlers, J., and Zöllner, E.: Enhanced biological carbon consumption in a high $\mathrm{CO}_{2}$ ocean, Nature, 450, 545-548, doi:10.1038/nature06267, 2007.

Riebesell, U., Bellerby, R. G. J., Grossart, H.-P., and Thingstad, F.: Mesocosm $\mathrm{CO}_{2}$ perturbation studies: from organism to community level, Biogeosciences Discuss., 5, 641-659, 2008, http://www.biogeosciences-discuss.net/5/641/2008/.

Rost, B., Zondervan, I., and Riebesell, U.: Light-dependent carbon isotope fractionation in the coccolithophorid Emiliania huxleyi, Limnol. Oceanogr., 47, 120-128, 2002.

Russel, A. D., Hönisch, B., Spero, H. J., and Lea, D. W.: Effects of seawater carbonate ion concentration and temperature on shell $\mathrm{U}$, $\mathrm{Mg}$, and $\mathrm{Sr}$ in cultured planktonic foraminifera, Geochim. Cosmochim. Acta, 68, 4347-4361, 2004.

Sarathchandra, S. U.: Nitrification activities and the changes in the populations of nitrifying bacteria in soil perfused at two different H-ion concentrations, Plant Soil, 50, 99-111, 1978.

Serpa, D., Falcão, M., Duarte, P., Cancela da Fonseca, L., and Vale, C.: Evaluation of ammonium and phosphate release from intertidal and subtidal sediments of a shallow coastal lagoon (Ria Formosa - Portugal): a modelling approach, Biogeochem., 82, 291304, 2007.
Sinha, V., Williams, J., Meyerhöfer, M., Riebesell, U., Paulino, A. I., and Larsen, A.: Air-sea fluxes of methanol, acetone, acetaldehyde, isoprene and DMS from a Norwegian fjord following a phytoplankton bloom in a mesocosm experiment, Atmos. Chem. Phys., 7, 739-755, 2007, http://www.atmos-chem-phys.net/7/739/2007/.

Strauss, E. A., and Lamberti, G. A.: Regulation of nitrification in aquatic sediments by organic carbon, Limnol. Oceanogr., 45, 1854-1859, 2000.

Suffrian, K., Simonelli, P., Nejstgaard, J. C., Putzeys, S., Carotenuto, Y., and Antia, A. N.: Microzooplankton grazing and phytoplankton growth in marine mesocosms with increased $\mathrm{CO}_{2}$ levels, Biogeosciences Discuss., 5, 411-433, 2008, http://www.biogeosciences-discuss.net/5/411/2008/.

Tanaka, T., Thingstad, T. F., Løvdal, T., Grossart, H.-P., Larsen, A., Schulz, K. G., and Riebesell, U.: Availability of phosphate for phytoplankton and bacteria and of labile organic carbon for bacteria at different $p \mathrm{CO}_{2}$ levels in a mesocosm study, Biogeosciences Discuss., 4, 3937-3960, 2007 , http://www.biogeosciences-discuss.net/4/3937/2007/.

Vogt, M., Steinke, M., Turner, S., Paulino, A., Meyerhöfer, M., Riebesell, U., Le Quére, C., and Liss, P.: Dynamics of dimethylsulphoniopropionate and dimethylsulfide under different $\mathrm{CO}_{2}$ concentrations during a mesocosm experiment, Biogeosciences, 4, 3673-3699, 2007a, http://www.biogeosciences.net/4/3673/2007/.

Vogt, M., Turner, S., Yassaa, N., Steinke, M., Williams, J., and Liss, P.: Laboratory inter-comparison of dissolved dimethyl sulphide (DMS) measurements using purge-and-trap and solid-phase microextraction techniques during a mesocosm experiment, Mar. Chem., 108, 32-39, 2008.

Wingenter, O. W., Haase, K. B., Zeigler, M., Blake, D. R., Sherwood Rowland, F. S., Sive, B. C., Paulino, A., Thyrhaug, R., Larsen, A., Schulz, K., Meyerhöfer, M., and Riebesell, U.: Unexpected consequences of increasing $\mathrm{CO}_{2}$ and ocean acidity on marine production of DMS and $\mathrm{CH}_{2} \mathrm{CII}$ : Potential climate impacts, Geophys. Res. Lett., 34, L05710, doi:10.1029/2006GL028139, 2007. 